\title{
Terrifying tales and practical advice for safe health care
}

\author{
Take as Directed: Your Prescription for \\ Safe Health Care in Canada \\ Rhonda Church and Neil MacKinnon \\ ECW Press; 2010.
}

I $\mathrm{n}$ the 10 years since I relocated to Halifax, Nova Scotia from Toronto, Ontario, I've had three family physicians. The first closed her practice to specialize in another area of medicine. The second returned to her home province. The third I've been seeing for the past four years and I pray she isn't planning to leave me anytime soon. Why? Because according to Take as Directed: Your Prescription for Safe Health Care in Canada, the chance that I'll find another family physician to accept me as a new patient - especially if I' $m$ in my senior years and riddled with health problems - is slim.

This book's coauthors have the inside scoop: Rhonda Church is a family physician in rural Nova Scotia and Neil MacKinnon is the associate director of research at Dalhousie University's College of Pharmacy in Halifax. Among their many credentials, Church chairs the Canadian Medical Association's Core Committee on Health Care and Promotion, while MacKinnon has been the lead investigator of several studies on the safety and effectiveness of Canada's medication-use system.

According to its press materials, the book was written in part to inform Canadians about the practical things they can do to prevent adverse events. It's also meant to be a guide on how to optimize the use of medications at home and avoid potential conflicts with herbal supplements and prescription medications. While it delivers on those promises, the practical advice tends to get lost in a sea of statistics and references.

The passages that will engage (and terrify) ordinary Canadians aren't the

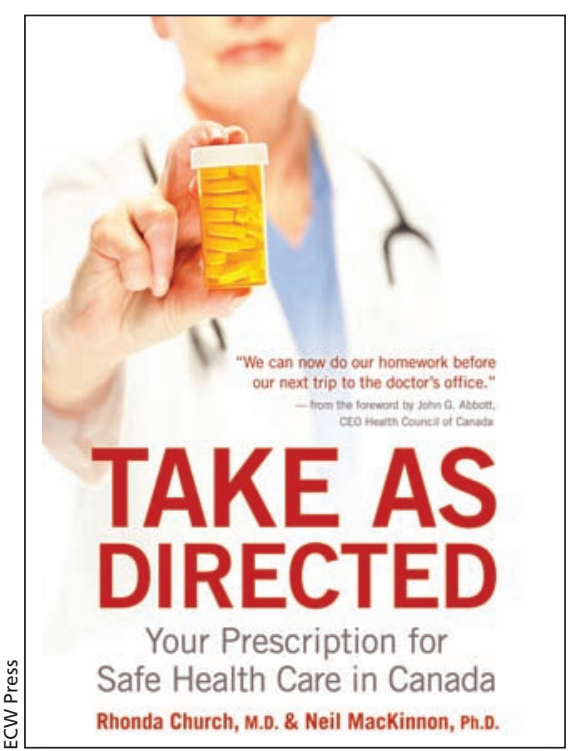

statistics and references. Rather, it's the fictional anecdotes based on the authors' experience in their professional practices that health care consumers will find compelling. In chapter one, "Paul's Peril: A Cautionary Tale," there's the story of how senior citizen "Paul" receives a prescription for antibiotics he didn't actually need for a cold virus from a harried physician at a hospital emergency department. The antibiotics interact harmfully with one of Paul's regular medications, which he didn't disclose to the doctor because he could not recall its name. Poor Paul ends up with a potentially life-threatening condition that can cause the disintegration of muscle tissue and kidney failure.

The authors are adept at painting these kinds of health-scare pictures. They're also skilled at presenting information in plain language, tossing in Maritime references to lighten depressing details, as in "Meanwhile, closures and service interruptions at emergency departments in more remote areas of the province are as common as fog off Peggy's Cove" and "a rising tide lifts all boats. ... In our case, the rising tide may be new disclo- sure guidelines for health professionals for reporting errors."

But what of the practical advice? In chapter three, "Rubber-gloved requiem," the authors urge patients to police their own health care, detailing how to do so in seven exhaustive steps that include being an active participant in the process, a recurring message throughout the book. It would seem that the days when doctors exclusively did the diagnostic detective work and follow-up for their patients have gone the way of the house call.

One thing is certain: Church and MacKinnon aren't afraid to expose the ever-widening gaps in Canada's health care system by comparing it to other sectors. They state that "The system that was designed forty-odd years ago is just that - a system that was designed to meet our needs as a nation forty-odd years ago. Imagine the airline industry trying to land planes at Toronto's Pearson airport using a system designed more than forty years ago, or security personnel relying on practices and policies from the same era."

Take as Directed has been well endorsed; it features seven testimonials from reputable organizations such as the Health Council of Canada, the Canadian Pharmacists Association and New York's Commonwealth Fund.

While ordinary Canadians will glean some insight into how to more effectively navigate the system, this book would be best read by physicians and other health care professionals. It should also be included in medical and pharmacy school curricula, for it illustrates that the healing of our fractured health care system must come from within.

\section{Jane Doucet BJH}

Health and medical writer and editor Halifax, NS

CMAJ 2011. DOI:10.1503/cmaj.101475 